\title{
PULLING OFF THE MASK OF LAW: A RENEWED RESEARCH AGENDA FOR ANALYTICAL LEGAL THEORY
}

\author{
Keith CULVER \\ Michael GIUDICE
}

Resumen:

El objetivo de este artículo es identificar y defender una parte de la renovada agenda de investigación de la teoría jurídica analítica: un renovado enfoque "relacional" sobre la manera de caracterizar el concepto de derecho - siguiendo la línea trazada por Hart de investigar la relación del derecho con la moral, la coerción y las reglas sociales-. Nosotros defendemos una investigación adicional de carácter descriptivo-explicativo sobre la relación que tiene el derecho con la seguridad, el medio ambiente y las tecnologías de la información, en el contexto de disposiciones jurídicas estatales y extra-estatales. Esta investigación responde a fenómenos jurídicos recientes del modo en que fueran identificados por la tesis inter-institucional de la legalidad desarrollada en nuestro reciente libro Legality's Borders (Oxford University Press, 2010), y asimismo responde a los intereses y a la perspectiva de una versión modernizada del "ciudadano ordinario" de Hart. Un renovado enfoque "relacional" proporcionará los medios para un análisis más profundo de las formas de legalidad que surgen al interior y alrededor del cada vez más inestable estado municipal, en la era moderna de una mayor interdependencia e interconexión entre las disposiciones jurídicas estatales y extra-estatales.

\section{Palabras clave:}

Jurisprudencia analítica, teoría inter-institucional del derecho, legalidad, positivismo jurídico relacional, análisis conceptual contextualizado, ciudadano ordinario. 
KEITH CULVER / MICHAEL GIUDICE

\begin{abstract}
:
This article identifies and advocates one part of a renewed research agenda for analytical legal theory: a renewed 'relational' approach to characterization of the concept of law, following the lead set by Hart's exploration of law's relation to morality, coercion, and social rules. We advocate further descriptive-explanatory investigation of law's relation to security, environment, and information technology, in the context of state and extra-state legal orders. This investigation is responsive to emerging legal phenomena as identified by the inter-institutional account of legality developed in our recent book Legality's Borders (Oxford University Press, 2010), and is further responsive to the interests and perspective of a modernized version of Hart's 'ordinary citizen.' A renewed relational approach will provide a means to deeper characterization of the forms of legality arising within and around the increasingly unsteady municipal state in the modern era of increased interdependence and interconnection amongst state and extra-state legal orders.
\end{abstract}

Keywords:

Analytical Jurisprudence, Inter-Institutional Theory of Law, Legality, Ordinary Citizen, Relational Legal Positivism, Contextualised Conceptual Analysis. 
PULLING OFF THE MASK OF LAW

Summary: I. Introduction. II. Analytical Legal Theory: Functions, Methods, Objects and Evidence. III. Contextualised Conceptual Analysis. IV. Conclusion. V. Bibliography.

\section{INTRODUCTION}

This article is a contribution to an unfortunately neglected genre of analytical legal theory: sympathetic yet comprehensive renovation of its research agenda. This renovation is motivated by the fact that analytical legal theory is in the midst of an identity crisis - or, at least according to its critics, it certainly ought to be. In the aftermath of Ronald Dworkin's celebrated response in "The Model of Rules I" to Hart's magisterial The Concept of Law, analytical legal theory appears to have lost track of its reason for being. The historical task of analytical legal theory is perhaps best expressed by its most colourful forefather, Jeremy Bentham. In a characteristically vivid use of metaphor, Bentham advises that we must "draw aside that curtain of mystery which fiction and formality have spread so extensively over the Law" and in criticism of Blackstone suggests that while "Law shews itself in a mask...this mask our author instead of putting off has varnished." Bentham decried, for example, Blackstone's approving report of the fiction contained in the doctrine that there was no need to publicise widely the acts of Parliament, since "every man in England is, in judgment of Law, party to the making of an Act of Parliament, being thereat by his representative." 2 This might make good legal sense, Bentham writes, but it is an affront

\footnotetext{
1 Bentham, Jeremy, A Comment on the Commentaries, Chap. II, s. 1 in The Collected Works of Jeremy Bentham, London, Great Britain, Clarendon Press, 1968, p. 124. This particular setting of Bentham's remarks is of course used in an essay by H. L. A. Hart, out of which some of our argument grows: "The Demystification of the Law" in Essays on Bentham, Oxford, Great Britain, Clarendon Press, 1982, p. 23.

2 Bentham, Jeremy, A Fragment on Government, in Burns, J. H. and Hart, H. L. A. (eds.), Introd. Harrison, R., Cambridge, Great Britain, Cambridge University Press, 1998, p. 17.
} 
to common sense. The job of legal theory is to confront the affront: to clarify what remains obscure about law, using morally neutral methods. While analytical legal theory continues to accept as the kernel of its task the job of pulling off the mask of law, the reasons why this goal is sought have varied, as have the methods deployed in pursuit of the goal. Disputes regarding the proper motivations and methods of analytical legal theory have taken so much effort that analytical legal theory gives the appearance of being in a state of perpetual preparation to reach its goal, with little demonstrable progress.

Some analytical legal theorists, such as Leslie Green, see a mixed record of progress in response to persistent questions of legal theory: "some broadening" of understanding in investigation of the relation between law and social rules, "some narrowing, some deepening" of understanding in investigation of the relation between law and morality, and "some paralysis" 3 and a "depressing" point of "stasis"4 in study of the relation between law and coercion. Yet Green does not advocate any great departure from past methods or question, and is seemingly content for analytical legal theory to continue work on its persistent questions, no matter the reactions of the "plain lawyers" who might never be convinced of the interest of those questions. 5 Few, however, are persuaded that this will result in the needed breakthroughs. David Dyzenhaus, for example, has called analytical legal theory a "stagnant research programme,"6

3 Green, Leslie, "General Jurisprudence: A 25th Anniversary Essay" (2005), 25 Oxford Journal of Legal Studies 4, 565-580, p. 575.

4 Ibidem, p. 573.

5 As Green explains at the conclusion of "General Jurisprudence: A 25th Anniversary Essay", “There have always been jurisprudence books that didn't discussion much law; now there are jurisprudence books that don't discuss much jurisprudence. Will plain lawyers find them interesting? Perhaps not; but we should remember that the editors of the Quarterly Review urged Charles Darwin to abandon the manuscript of The Origin of Species and instead write about pigeons, because 'everyone is interested in pigeons.' And perhaps we should be glad the advice was ignored". Ibidem, p. 580.

6 Dyzenhaus, David, "Positivism's Stagnant Research Programme" (2000), 20 Oxford Journal of Legal Studies 4, 703-722. 
whose increased precision in specification of claims and methods has generated increasingly sophisticated defence of increasingly limited theoretical ambitions. As Jeremy Waldron put it, "Most of those who bask in Hart's glory prefer to fiddle with issues about exclusive and inclusive legal positivism, a discussion that has been following the law of diminishing returns since Jules Coleman initiated it in 1988, rather than address... more urgent and compelling issues." Others are less kind in their assessment of the sophisticated parochialism they see, charging that the enterprise of analytical legal theory risks collapsing into itself, leaving little more than a goal and endless quibbles over method. As Brian Simpson memorably assesses the postConcept progress of analytical legal theory,

In a sense it has been downhill all the way-downhill, that is, from the lucidity and elegance of Herbert's writing to the unattractive elaborations of some of his critics and defenders, downhill from Herbert's direct analysis of law and legal institutions to writings about what other people have said about what other people have written about law and legal institutions. In British military circles there was, in my time, a bawdy monologue, much recited in pubs, which took the form of a bestiary. One of the creatures featured in it was the $\mathrm{Fu}-\mathrm{Fu}$ Fly, which was said to fly in ever diminishing circles until it finally vanished up its own bottom, from which secure if unsanitary location it looked out at the world with scorn and derision. That, leaving on one side scorn and derision, is more or less the present picture in relation to much of the secondary literature on The Concept of Law. ${ }^{8}$

Simpson's despairing picture leads us to a simple question: what next for those intrigued by analytical legal theory yet frustrated by its offering deflections and defences rather

7 Waldron, Jeremy, "Hart and the Principles of Legality", in Kramer, M. H. et. al. (eds.), The Legacy of H. L. A. Hart: Legal, Political, and Moral Philosophy, Oxford, Great Britain, Oxford University Press, 2008, p. 69.

8 Simpson, Brian, "Herbert Hart Elucidated" (2006), 104 Michigan Law Review 6, 1437-1460, pp. 1455-6. 
than advances? One option is to adopt an entirely new research agenda, perhaps taking a direction like that pioneered by Brian Tamanaha in his 'socio-legal positivism. ${ }^{99} \mathrm{~A}$ rather more promising option, we shall argue, lies in a line of argument we began in our recent Legality's Borders. The inter-institutional theory of law elaborated there is an attempt to marshall overlooked insights of analytical legal theory in support of sympathetic, yet ground-up renovation of analytical legal theory sufficient to enable explanation of legality in diverse forms within and beyond the state. The argument of Legality's Borders contributes, we believe, to the extrication of analytical legal theory from stagnation, and re-orientation toward pressing problems whose salience is rooted in the experience of ordinary citizens encountering diverse forms of legality in a world in which the law-state appears prominent, yet no longer dominant. This article continues the methodological amplification started in Legality's Borders, turning from the expanded range of legal phenomena we investigated in Legality's Borders, to an attempt to deepen the analytical account of legality as it is found in those diverse phenomenal contexts. Where our inter-institutional theory was developed and deployed to enable characterisation of prominent forms of legality in addition to the law-state, this next, complementary step is an attempt to better understand the nature of legality in some of those extra-state situations. This approach is not, however, straightforwardly a continued investigation of intrastate, trans-state, supra-state, and super-state legal phenomena. ${ }^{10}$ Rather, it is an attempt to deepen understanding of prominent manifestations of legality, in whatever state or non-state form they occur, by expansion of an approach begun by Hart, yet left behind as enthusiasms led elsewhere. What has been called Hart's 'relational approach' to the

9 Tamanaha, Brian, "Socio-Legal Positivism and A General Jurisprudence" (2001), 21 Oxford Journal of Legal Studies 1, 1-32.

10 See Culver, Keith, and Giudice, Michael, Legality's Borders, New York, United States, Oxford University Press, 2010, pp. 148-171. 
concept of law sought to explain that concept by way of its relation to social rules, morality, and coercion. The results of this investigation are well-known, as are the results of its newer champions. What is less well-recognized is the fact that Hart did not suppose his choice of these particular relations was in any way exhaustive, and certainly not exclusive. Rather, these relations appeared salient from the point of view of the ordinary educated person to whom his theory was nominally addressed. Hart might have done otherwise. He might, for example, have chosen the relation between law and religion, or he might have added the relation between law and liberty, which he treated later in the celebrated Hart-Devlin debate. His choice of the focal relations of The Concept of Law was just that: a choice, made in light of the interests of a particular audience engaged from a particular explanatory and historical perspective, in which the relations explored matter not just individually, but collectively. We aim here to take up Hart's approach and insight to further develop the relational approach, renewed in the context and perspective of the citizen in the age of globalization. In that context we turn from Hart's chosen relations to those relations individually and collectively salient to our citizen's perspective as a member of a state made unsteady by dynamic mixtures of social and natural pressures: the relations between law and security, law and technology, and law and environment. The precise way in which we engage those relations will produce a contextualised concept of law capable of serving as a bridge between descriptive-explanatory approaches to legal theory, and the empirical phenomena those theories engage.

Before we explore those relations and their product, however, we must take up the prior questions of the nature and benefits of a renewed relational approach to the concept of law, and the still earlier question of how such an approach might be divorced from the dismal mis-steps which have led to analytical legal theory's stagnation. We should aim, at very least, to see where analytical legal theory went wrong, 
so we might attempt to replace present stagnation with a renovated research agenda giving fresh life to Bentham's clarity of purpose and ambition.

\section{Analytical Legal Theory: Functions, Methods, ObJects And Evidence}

It is probably impossible to conduct a kind of social archaeology which might reveal precisely the chain of events leading from Bentham's confident goal-setting, through Hart's inspiring re-statement of legal positivism, and on to the present state. Fortunately, for our purposes, no such archaeology is necessary. We are seeking less to isolate a point of error from which the correct path might be rejoined, and rather more to understand where the debate lost its way as a dialogue amongst scholars. With this purpose in mind, let us explore a suggestion visible in Brian Simpson's remark that analytical legal theory has become too little concerned with "direct analysis," and too much a debate regarding "what other people have said about what other people have written." What Waldron and Simpson see as a distracting preoccupation with words about words, rather than words about things, is perhaps nobler than suggested by the Fu-Fu fly's backward trajectory. It may be that analytical legal theory has been something of a victim of its own openness to criticism, launching too eagerly into dialogue regarding questions adjacent to its main job. This possibility is visible in the way debate has been drawn into response to questions it should perhaps have rejected as secondary questions to be answered after further efforts at theory building, not in medias res. Entanglement in these questions has resulted, we argue below, in a dialogue which has left analytical legal theory simultaneously too narrow and too broad, in need of a substantial middle we aim to supply. More specifically, and as we have argued elsewhere, ${ }^{11}$ analytical legal theory has been distracted by at- 
tempted response to three sometimes concurrent demands it demonstrably need not engage. The 'practicality demand' asks that analytical legal theory become a kind of practical philosophy aimed at least partially at giving tools of understanding to lawyers and private citizens - a demand associated with Green's 'plain lawyers.' The practicality demand sometimes arrives in the company of the 'normativity demand,' the demand that any theory of law capture law's distinctive normative function in a wholly theoretical way, independent of any particular system. Both practicality and normativity demands are sometimes found in conjunction with a third demand, the insistence that analytical legal theory must somehow be total, exhaustive and utterly self-sufficient, a contender for the title of 'best comprehensive understanding of law as a whole.' These demands are hardly unreasonable as representations of the diverse interests inquirers may bring to the activity of understanding legality; yet from the fact that these are reasonable interests, nothing follows about whether a valuable contribution to our understanding of legality must satisfy any one or all of these interests. These are not the only justifiable interests in legality - a valuable contribution to understanding of legality might address altogether different interests. More importantly, there is little reason to suppose that response to these interests must come from analytical legal theory. In fact, as we aim to show below, the greatest value in these demands may lie not in their value as demonstrations of the shortcoming of analytical legal theory, but in their pointing the way to needed renovations of analytical legal theory sufficient to enable it to connect appropriately with other data, arguments, and insights into legality in its many forms.

In suggesting that analytical legal theory has become both too narrow and too broad, we are identifying coincident problems whose origin is more an epiphenomena of a

Culver, Keith, "Leaving the Hart-Dworkin Debate" (2001), 50 University of Toronto Law Journal 4, 367-397. 
dialogue than a consequence of theory-building goals or methodological commitments and operations. The roots of these problems in dialogue is a key to understanding how analytical legal theory has strayed from its motivating goal and descriptive-explanatory methods, and in turn key to understanding how renovation of the approach might take up and extend its original insights. In this context, what is perhaps most surprising about the crippling narrowness identified by Green, Waldron, Simpson and others is the fact that the criticism is not new. In fact, it is a danger explicitly acknowledged by analytical legal theorists, particularly in handling of the phenomena of adjudication in response to the practicality demand. As Hart lists the accusations evident in the demand, "the sin imputed to positivist conceptions of the judicial function was 'formalism', 'conceptualism', 'mechanical' or 'slot machine' jurisprudence or an excessive belief in the use of 'logic' in reaching decisions." 12 In early response to these charges, legal realists took up the new methods available from psychology and sociology to throw light on the all-too-human dimension of judges as flesh-and-blood reasoners capable of misinterpretation, political bias, and other motivations with the potential to limit the likelihood of impartial application of rules with determinate meaning. A few of these realists took theorists to task for omitting other dimensions of courtroom life, as Jerome Frank did in chiding his colleagues "for forgetting juriesprudence" 13 which might additionally take account of the role of juries. Yet for the most part, response to the practicality demand led to an unquestioned focus on the pivotal role of the judge, and surrounding investigation of the nature of legal concepts treated judicial use of legal norms as the crucible for theories of law. Later in the century H. L. A. Hart's attempt to avoid undue nar-

12 Hart, H. L. A., "Law in the Perspective of Philosophy", in Essays in Jurisprudence and Philosophy, Oxford, Great Britain, Clarendon Press, 1983, 145-158, p. 152 .

13 Frank, Jerome, "Preface to the Sixth Printing" in Law and the Modern Mind, Gloucester, Massachusetts, Peter Smith, 1970. First published in 1930. 
rowness by means of a broader theory of social rules soon collapsed into a similar fate. Hart's pioneering use of the idea of social rules accepted and applied by generically identified 'officials' became enmeshed in the deep but narrow Dworkin-initiated debates regarding judicial discretion. Here our purpose is limited to diagnosis of just where the dialogue fell away from the purportedly central goals of analytical legal theory, so we will not fall back into discussion of theoretical characterisation of adjudication. It is worthwhile nonetheless to quickly illustrate the deficiencies of the judge-centred approach to the adjudicative enterprise, beyond Frank's pointed observation about the importance of juries.

It seems to be easily forgotten that judges do not operate in isolation. There are other players within and without the courtroom who can influence very significantly the context in which judges carry out their work. With the advent of the Charter of Rights and Freedoms in Canada, for example, interveners play a role in Supreme Court decision-making which is only now beginning to be examined by scholars based mostly in university departments of Political Science. The most frequent interveners are the Women's Legal Education and Action Fund and the Canadian Civil Liberties Association. It is perhaps still unclear just what effect interventions by these groups have, but evidence is growing that there is some effect rather than none, leading sometimes controversial scholars Ted Morton and Rainer Knopf to identify a so-called 'Court Party' of diverse political interests which seek political change through politicization of the judicial process. ${ }^{14}$ Sometimes these interveners carry out their intervention for reasons unconnected to the case at bar, as, for example, when LEAF intervened in Andrews $v$ Law Society of British Columbia ${ }^{15}$ to satisfy its own interest in bringing the court to interpret equality provisions of the

14 Morton, F. L. and Knopff, R., The Charter Revolution and the Court Party, Peterborough, Ontario, Broadview Press, 2000, Chapter 1.

15 Andrews $v$. Law Society of British Columbia [1989] 1 S.C.R. 143. 
Charter. There may be still other factors only a little beyond the courtroom which directly influence judges' task. Prosecutorial discretion, for example, determines which laws are in fact applied and brought before judicial interpreters. Unpopular laws may become functionally obsolete as prosecutors consciously cease relying on them, all without judicial attention to the nature of the norm expressed in the obsolete law. (We might call this desuetude in fact as opposed to desuetude by rule of positive law, as is permitted in, e.g., Scotland). None of these facts are novel or unavailable to analytical legal theorists, and these sorts of facts were top of mind in Frank's and Hart's response to accusations of formalism. Later analytical legal theorists' entanglement in narrow questions of judicial activity is almost incomprehensible in light of the availability of earlier warning against just this sort of narrowness. Yet seen from the point of view of theorists peppered by versions of the practicality demand by 'plain lawyers' and their sympathizers, it is entirely understandable that these theorists have paused to extinguish this kind of flaring up of criticism, before pressing on with pulling off the mask of law in a way more sensitive to the wide range of phenomena properly examined by a descriptive-explanatory theory. The derailing of a research agenda by the practicality demand is interesting in itself as a tale of changing enthusiasms and misplaced effort, but what is far more interesting about the drain of philosophical energies toward questions about judges comes in the effect of this work on arguments addressing more general questions about the nature of the concept of law and legal system, the nature of legal obligation, acceptance and fidelity to law, and associated concepts of duty, permission, right, and so forth.

There is a curious knock-on effect from analytical legal philosophy's deep but narrow response to accusations of arid conceptualism. The general-level picture of the nature of law and legal system built on the back of the Anglo-American judge-focussed picture of brute phenomena 
overemphasises the importance of judges as legal officials at the cost of losing touch with legal phenomena purportedly captured by these pictures, particularly with the addition of the inclusive vs. exclusive positivism debate and its devolution into a debate over the logic of intra-theory differences. The key features of the general picture are quite simple: a legal system may be said to exist when officials accept and private citizens at least obey certain authorised norms as non-optional standards of conduct. The validity of authoritative norms is expressed by the collective commitment and practice of officials, whose recognition of certain norms as authoritative provides a master rule of validity for the system. This picture is placed under serious theoretical strain by two empirical factors: the increasingly elusive nature of the class of officials, and the increasingly porous nature of nominally discrete legal systems.

Hart's famous sketch of a primitive legal society under the rule of Rex I was meant as a notional construction, yet at some points in history reality bore a substantial resemblance to theory. The most famous of the Icelandic sagas, Njal's Saga, tells of a rudimentary legal order in which authoritative legal norms were verified by the law-speaker, who could be consulted by disputing parties to confirm the existence of a particular legal norm. ${ }^{16}$ The rule of recognition was maintained and passed on by the requirement that the law-speaker provide an annual recitation of all of the laws, so the system was evidently quite simple, or the law-speaker possessed remarkable skills of memorisation. Modern municipal systems of law are significantly different from this isolated island society and its slim set of authoritative norms. As we have already observed, a wide range of complex forces - some local, and some apparently universal- bear on judges making determinations of law. These forces are poorly represented by the kinds of model officials, nearly always model judges, depicted in general theories of

16 Njal's Saga, trans. Bayerschmidt, C. F. and Hollander, L. M., Ware, Herts, Wordsworth Editions, 1998, Ch. 97 n. 5. 
law delivered by analytical legal theory and its interlocutors. Dworkin's Hercules, ${ }^{17}$ and Jules Coleman's recent development of the Swede, ${ }^{18}$ seem to resemble more closely the kind of official envisioned in the Icelandic sagas than the diverse range of officials evident in modern municipal systems of law. Both Dworkin's Hercules and Coleman's Swede function as model authorities at a crucial nexus point, Dworkin's in the context of a court, and Coleman's as a kind of special epistemic authority regarding the identity of legal norms in a system which is not the object of the Swede's normative allegiance. These choices of illustrative character each refer to a nexus point of testing for normative authority which is under threat by empirical change from within the fragile borders of discrete municipal systems, and from without. As William Twining has argued, "globalisation and interdependence challenge 'black box theories' that treat nation states or societies or legal systems as discrete, impervious entities that can be studied in isolation either internally or externally." 19 Familiar examples of penetration of municipal legal systems can be seen in the effect of international trade law on domestic legal practices, and the demands placed on states by international law-governed human rights violations in other states. Recently, the collapse of state isolation was illustrated in the conduct of the United States, the global leviathan historically tempted toward an isolationist stance. The BBC World Service reported that freshly declassified US documents show that senior American officials were warned in plain terms of impending genocide in Rwanda, yet chose nonetheless to vote with the remainder of the UN Security

17 Dworkin's fictional judge of superhuman powers is most prominently used in his Law's Empire, Cambridge, Massachusetts, Belknap Press of Harvard University Press, 1986.

18 Coleman, Jules, The Practice of Principle, Oxford, Great Britain, Oxford University Press, 2001.

19 Twining, William, Globalisation and the Legal Theory, London, Great Britain, Butterworths, 2000, p. 51. See also Twining, William, General Jurisprudence: Understanding Law from a Global Perspective, Cambridge, Great Britain, Cambridge University Press, 2009. 
Council to withdraw troops from Rwanda. According to the BBC, "In May [1994], a Pentagon memo cautioned against using the term 'genocide' to describe the Rwandan massacres, as under the 1948 Genocide Treaty, this could legally oblige the UN, and by extension the US, to act. 'Genocide finding could commit USG (US Government) to actually 'do something', the memo warned."20 This example illustrates neatly the extent to which identification of officials of a particular discrete legal system is increasingly difficult, and perhaps more importantly, how judge-focussed accounts of officials in general-level analytical pictures of law as an inhabitant of discrete legal systems omit demonstrably important phenomena. In the instance cited, the US plainly feared a kind of external legal source and legal official triggering a significant change to its legal position, and in turn its policy position. Of course, it is entirely possible for a critic sympathetic to a rule of recognition plus official acceptance account of the concept of law to respond in various ways including insistence that the events of the example are interesting not because they show the interdependence of the American legal system with other sources of legality, but because the talk of a trigger to action shows precisely how that system remains autonomous to the extent that there is some final choice to be made by officials in the event that the trigger is tripped. Or perhaps one might say there was some antecedent recognition-carrying choice to join a treaty which foresaw just this sort of event. Yet as we argued at length in Legality's Borders, while this style of response might be effective against occasionally encountered challenges to the explanatory power of the orthodox view, the rise of intra-state, trans-state, supra-state and super-state legality is so extensive and so pervasive that a theory which fails to engage those novel phenomena risks losing any claim to being meaningfully

20 BBC World Service Tuesday 212001 August, Africa page, "US Warned about Rwanda Genocide." http://news.bbc.co.uk/2/hi/africa/1502708.stm Accessed 14 December 2011. 
descriptive-explanatory. Instead of pulling off the mask of law, such an approach risks becoming an apologist for fictions. ${ }^{21}$ Worse yet, a state-centric rule of recognition plus official acceptance approach risks embracing a fiction which Hart saw and railed against in Austin - the misleading view that law-states are or ever have been autonomous in the sense required by Austin's uncommanded commander. The deep but narrow gains made in exploration of social rules appear to have given rise to a general jurisprudence whose attempts at response to comprehensiveness and normativity demands lead them to a picture of law so broad and abstract that it is no longer clear just how they are descriptive-explanatory, and still less clear how these investigations are connected to the remainder of Hart's original investigation of the relations between law, social rules, morality and coercion, all in aid of a richer picture of law developed from the perspective of the ordinary citizen. The results may be satisfying to some, ${ }^{22}$ bravely holding their analytical course and ignoring calls to do otherwise. Yet it seems to us that this amounts to bravely holding to a course which has been subtly altered by the force of a dialogue which has left its original goal, motivation and audience behind, forgetting Bentham's and Hart's urging clarity in understanding law as a social institution, practice and experience. We have tried to indicate above some ways in which narrowness and overbreadth are evident in the careers of devices such as Hercules, the Swede, and the Uncommanded Commander. Still more pressing shortcomings are evident in the fact that even if all were well with investi-

21 We are not alone in this assessment. See, for example, Tamanaha, Brian, $A$ General Jurisprudence of Law and Society, Oxford, Great Britain, Oxford University Press, 2001; Twining, William, General Jurisprudence: Understanding Law from a Global Perspective, Cambridge, Great Britain, Cambridge University Press, 2009; Von Daniels, Detlef, The Concept of Law from a Transnational Perspective, Surrey, Great Britain, Ashgate Publishing, 2010; and Santos, Boaventura de Sousa, Toward a New Legal Common Sense: Law, Globalization, and Emancipation, 2nd edn., London, Great Britain, Butterworths, 2002.

22 Perhaps those who suppose they are the Darwins in Green's metaphor. See Green, Leslie, op. cit., n. 5. 
gation of law and social rules and morality, there is still the "stasis" observed by Green with respect to coercion, and worse yet, as Green writes, "What we have not had is convergence."23 The absence of convergence in investigation of social rules, morality and coercion is particularly troubling in light of the contingent relevance of these relations to an understanding of law satisfactory to inquirers' interests. The relation of law to those particular relations was judged important by Hart in his deepening of a picture of those features of legality particularly salient to ordinary citizens. We have already suggested that Hart might have chosen other relations to investigate, and in other work did so. What does it say about the progress of analytical jurisprudence that it has made little headway toward an integrated picture of just three of the contingent relations relevant to a citizen whose interests may well change? As we suggested in Legality's Borders, we would do well to conduct legal theory from the perspective and interests of the ordinary citizen who travels in a globalizing world whose effects are felt at home and when travelling. The interests of that citizen are at best partially satisfied by the partial advances of Hercules, the Swede and friends in a subset of the relations between legality and its wider social context. The citizen of $L e-$ gality's Borders demands more: a wider relational approach, with better integration, resulting in a concept of law whose claim to be descriptive-explanatory is grounded in a clear account of the responsiveness the theory owes to social evidence, and fidelity to its goal of clarification such that practicality, normativity, and comprehensiveness demands can each be given their proper space and no more. In a phrase, the ordinary citizen of the $21^{\text {st }}$ century demands a 'contextualised conceptual analysis' whose deployment of Hart's relational approach renews analytical jurisprudence in a way which overcomes its narrowness and overbreadth while acknowledging the limits of analytical jurisprudence

23 Green, Leslie, op. cit., n. 3, p. 575. 
and the value of other theoretical and empirical approaches to law.

\section{Contextualised Conceptual ANALysis}

In this paper we limit ourselves to sketching the nature and role of the kind of contextualised conceptual analysis we suppose needs to be developed, leaving its full development to future work. This analysis is a continuation of the approach begun in Legality's Borders. There we sought to develop a 'bottom-up' phenomena-sensitive explanation in which our account of legality as agglomerations of institutions of law operated as kind of radar or detection device. Our inter-institutional account is capable of detecting manifestations of legality in both familiar areas of social life such as the law-state, and in less familiar areas of transand super-state legality. That account is intended as one kind of contribution to the broadest possible picture of law, surfacing for further examination several instances of legality given insufficient attention by contemporary analytical jurisprudence. The difference between our inter-institutional theory and our present effort is usefully expressed by way of a spatial metaphor: where our inter-institutional theory enables detection of peaks and promontories of legality on the terrain of social life, this paper and contextualised conceptual analysis aim to enrich our account of those promontories by beginning to examine the relations between legality as found there, and other social forces salient from the perspective of our ordinary citizen who travels and finds legality in the law-state, intra-state, trans-state, and super-state situations we have previously characterised. The resulting conceptual analysis is contextualised in three ways. First, in our advancing the relational approach toward previously underexamined relations between law and other social phenomena, we aim to be responsive to social phenomena salient from the point of view of the ordinary citizen who travels, undertaking what 
in Legality's Borders we called "re-socializing a descriptive-explanatory view of law." Contextualised conceptual analysis aims in this way to fill the hole left by overly narrow theorizing generating a distorted general jurisprudence whose claims to descriptive-explanatory relevance are at best difficult to credit, as discussed above. Second, our use of an expanded relational approach is intended to contribute to contextualised conceptual analysis by conducting a history-sensitive style of analysis, not just narrowly sensitive to legal history or the history of salient social phenomena in relation to legality, but to the fact that our concepts have histories as they have evolved in our understanding and as reflections of practice. Third, our expanded relational approach is contextualised in the sense that it follows and is complementary to our inter-institutional analysis, and is situated as one component of a broader conceptual-explanatory context, in which we claim we are not liable for direct response to practicality, normativity and comprehensiveness demands, yet we accept that we are reasonably held liable for the intersection of our view with theories responding directly to those demands. It will be characteristic of this expanded relational approach that it produces a concept of law which is vague, yet tolerably vague, as the story of law's relations to salient social forces is a story of a dynamic concept constantly under renewal in response to novel phenomena.

The remainder of this paper is devoted to exploration of these three aspects of contextualised conceptual analysis, motivated by the shortcomings of analytical theory, identified as a kind of narrowness in engagement of social phenomena, mistaken inference to generality from that limited set of data, and failure to situate analytical theory relative to other reasonable demands made of legal theory considered in toto and not just in its pre-censorial, clarificatory and expository mode. The very last part of this paper will discuss the particular relations we propose to engage in future work as a way to broaden the phenomenal basis of an- 
alytical legal theory. It will be useful to approach that discussion via further consideration of the sense in which contextualised conceptual analysis is historically sensitive and self-consciously a partial contribution to the broadest possible picture of legality, by way of beginning to respond to the problem of unselfconscious abstractness evident in analytical legal theory to date.

\subsection{History}

Analytical jurisprudence has long attempted to take history seriously in various ways, but those attempts have been arguably unselfconscious: history has mattered as an input to jurisprudential reasoning, not as an aspect of it. We propose a broader role for history in contextualised conceptual analysis, understanding that the concept of law and subordinate concepts have a more than etymological history, and that this history matters to the way we understand them now, particularly when aiming at something like a universal concept of law applicable to all societies at all times. Let us explain this claim in situ. One of the problems which has vexed analytical legal philosophy is understanding of the nature of legal obligation -how laws obligate, why subjects obey laws, and so forth. A typical analytical approach to the question of the nature of legal obligation is to examine first the meaning of obligation, and then to rely on that rich understanding of the meaning of the concept to try to understand the place of that concept in the surrounding web of legal concepts such as duty and permission. Lon Fuller, for example, writes of fidelity to law as a kind of translation of the attitude of acceptance of law, and builds the notion of faith, the Latin fide, into the account of how law presents itself to subjects in a way which secures their acceptance. ${ }^{24}$ Hart contributes the observation that 'obligation' seems to have its roots in the Latin ligare,

24 Fuller, Lon, The Morality of Law, 2nd edn., New Haven, United States, Yale University Press, 1969, pp. 38-41. 
to bind, and works from there toward ideas developed in a better known, and likely better worked fashion by Joseph Raz, in his understanding of legal norms as a special variety of exclusionary reasons. ${ }^{25}$ Yet all of this seems to be a half-step where a full step is needed. Some concepts have deeper historical roots than others, and the changes some concepts undergo over the course of their history may reflect special characteristics of that concept. Those special characteristics may in turn require special handling in any understanding of that concept and the conditions under which it is applied. Legal obligation seems to us to be one of these concepts whose historical career presents variations in meaning which are more than surface deep.

Understanding obligation as rooted in ligare, a binding tie, may capture a subtly yet importantly different dimension of the practice thought to be represented by descriptive-explanatory accounts of lived experience which inform the concept. To understand choice of conduct consistent with legal obligation as a choice to which one is bound is to invoke a metaphor which captures a sense of helpless involuntariness, and a constraint imposed from without. It may well be true that this understanding of legal obligation, built out of Roman use of obligatio generated from ligare, represents adequately the historical development of one use of the term and one contribution of experience to the shared concept. Yet this understanding may be unduly narrow, and a poor basis for an understanding of the concept of legal obligation as part of a broader understanding of adjoining legal concepts of permission, duty, and so forth. In

25 See Hart, H. L. A., The Concept of Law, 2nd edn., Oxford, Great Britain, Clarendon Press, 1994, p. 87; "Commands and Authoritative Reasons" in Essays On Bentham, Oxford, Great Britain, Clarendon Press, 1982, 243-268. See also Raz, Joseph, The Authority of Law, Oxford, Great Britain, Clarendon Press, 1979; "Authority, Law and Morality", (1985) 68 The Monist, pp. 295-324; "Authority and Justification" (1985) 14 Philosophy and Public Affairs 3, pp. 3-29; "Postscript to the Second Edition: Rethinking Exclusionary Reasons" in Practical Reason and Norms 2nd edn., Princeton, New Jersey, Princeton University Press, 1990, 178-199; "Explaining Normativity: On Rationality and the Justification of Reason" (1999) 12 Ratio, 354-379; Engaging Reason, Oxford, Great Britain, Oxford University Press, 2000. 
Bertram Wyatt-Brown's essays on the ideal of honour in the antebellum American South, ${ }^{26}$ he remarks on the arguments made by pre-revolution Americans seeking some form of self-rule that taxes sought by the English crown "were supposed to be considered as 'free gifts,' and as such could be offered only by the elected representatives of those who possessed the property thus given."27 As Edmund Morgan reads Wyatt's argument, "In depriving them of the sole right to tax themselves, the right to offer whatever they gave in taxes as a free gift to their king, Parliament deprived them of honour" 28 and collapsed the relationship which served as the precondition of a legal obligation to pay tax. These pre-revolution Americans seem to have understood legal obligation as something quite different from an externally imposed tie that binds. For these Americans, legal obligation sprung from an internally generated sense of honour as the autonomously chosen, internally generated entering into a liberty-limiting obligation. Any externally coerced compliance to some norm was to be resisted as strongly as possible.

We do not aim to suggest that either of these examples - ligare or free 'gifts' - illustrates the uniquely correct understanding of the concept of legal obligation, yet at the same time we do not wish to discard either one as an historical anomaly. It may be possible to integrate these ideas into some part of the contemporary analytical account of legal obligations as a special kind of reason, excluding other reasons for action, and accepted in that role for any reason at all, as Hart supposes, or because the exclusionary reason expresses some normally justified course of action, as Raz supposes. Yet even if these ideas cannot be incorporated into the contemporary account, it is far from clear

26 Wyatt-Brown, Bertram, The Shaping of Southern Culture: Honour, Grace, and War, 1760s-1880s, Chapel Hill, North Carolina, University of North Carolina Press, 2000. See also Edmund Morgan's review, "The Price of Honour", New York Review of Books XLVIII, No. 9, May 31, 2001, pp. 36-38.

27 Morgan, ibidem, p. 37.

28 Idem. 
that we are justified in discarding one as anomalous or an outlier and simply picking the other, perhaps ligare, as the etymologically nearest cousin to what we mean by legal obligation today. At least two options are opened by the historical wariness we think ought to be characteristic of an appropriately contextualised conceptual analysis. We might choose to modify the account of legal obligations as exclusionary reasons accepted by legal subjects for certain kinds of reasons, choosing to understand historical accounts of the binding force of legal obligations as indications of contextually variable perceptions of what counts as a normal reason for action, capable of bearing special force once recognised as a legal reason for action. Or we might choose to revisit the adequacy of this account of legal obligations. We might recognise that the contemporary social situation reflected in doctrines such as Raz's exclusionary reasons approach to legal obligation is itself a historical product concerned with a concept which is evolving through its use. Or we might imagine still further options for response. Yet doing nothing about the deep historical roots of these varying ideas about legal obligation would be a mistake which we ought to resist on the grounds that doing so would lead into acceptance of an undesirable descriptive-explanatory dissonance: we ought not to accept those pictures of legal obligation which capture some aspect of contemporary practice while making it difficult or impossible for us to understand at the same time the practice of legal obligation in these historical contexts. Laws are conventional products, and the conventions which produce them have histories which are part of a full understanding of the product. Historically-sensitive, perhaps historically 'inclusive' theorising may result in an understanding of the concept which is capacious and vague as it incorporates quite different societies and times, but that is scarcely an objection if possession of that concept enables us to understand better the very wide variety of ways of living life under law, avoiding the well-known trap of undue 
narrowness giving rise to Hercules, the Swede, and the Fu-Fu fly.

\subsection{The Contextualised Concept in Legal Theory as a Whole}

Having gone this far to emphasise the importance of history in understanding the meaning of concepts, we must be clear that our contextualised approach to the concept of law requires further methodological innovation beyond recognition that concepts do not arrive history-free. The second element of contextualised conceptual analysis is derived from an argument Culver made in a characterisation of H. L. A. Hart's picture of the concept of law. ${ }^{29}$ That argument attributed to Hart what Culver called 'relational legal positivism,' a method of concept-reconstruction which begins from what might be called a folk understanding of the concept of law, and builds a dynamic, changeable concept out of its relations to other phenomena. This concept of law is a kind of reflection of changes beneath it, a concept modified according to the results of ebbing and flowing changes in life under law. This approach, which Hart once recognized as 'hermeneutic, ${ }^{30}$ has been taken up by some analytical theorists, including, for example, Jules Coleman, whose support of a pragmatic method for analytical legal philosophy extends to acceptance of the need for our concepts to be revisable, and continuous with the social sciences, while not being supplanted by them. ${ }^{31}$ Coleman's powerful pragmatism is, however, hampered by a lack of clarity about its place relative to the normativity, practicality, and comprehensiveness demands. His assertion that

29 Culver, Keith, op. cit., n. 11.

30 See MacCormick, Neil, H. L. A. Hart, 2nd edn., Oxford, Great Britain, Oxford University Press, 2008, pp. 46 and 184; and Hacker, P. M. S., "Hart's Philosophy of Law", in Hacker, P. M. S. and Raz, Joseph (eds.), Law, Morality, and Society: Essays in Honour of H. L. A. Hart, Oxford, Great Britain, Clarendon Press, 1977.

31 Coleman, Jules, op. cit., n. 18, p. 201. See also Leiter, Brian, Naturalizing Jurisprudence, Oxford, Great Britain, Oxford University Press, 2007, Part II. 
the pragmatic method is always responsive to all of these concerns seems to leave his theory aiming to capture absolutely everything, which is plainly at odds with the nearly total absence of empirical data in his analysis, and his use of abstract devices such as the Swede, nominally independent of particular legal systems. Contextualised conceptual analysis aims to improve upon Coleman's pragmatism by being clear about its sources, the limits of its aims, and clear about the reasons why those aims are properly sought using the descriptive-explanatory relational approach. This analysis recognises the incompleteness of the relational approach as a way of understanding social phenomena, and rests its value on the clarificatory power it can bring to our otherwise potentially confused understandings of the concept of law and subordinate legal concepts, all contributing to the widest possible understanding of the promise and limits of law as a mode of organising social life. This limits the relational approach and contextualised concept of law to a role which is admittedly impractical and non-comprehensive. Contextualised conceptual analysis recognises that it is not an attempt to provide the best comprehensive theory of law as a whole, and remains agnostic regarding the character of non-philosophical investigations best suited to carrying out empirical and local-level theoretical investigations which inform the project of conceptual analysis. Investigations in sociology and anthropology of law, for example, are welcomed by contextualised conceptual analysis, yet this analysis holds no particular view regarding the methodology of sociology or anthropology. This analysis is nonetheless cautiously universal about the concept of law, in the sense of attempting to clarify the concept as a universally applicable concept. The clarificatory power of the contextualised concept of law is derived from two dimensions of its method, together with a careful admission about the limits of that analysis. Contextualised conceptual analysis understands through its sensitivity to history that while legal philosophy can be concerned with general or 
universal concepts, life under law is fundamentally local. Historical sensitivity allows contextualised conceptual analysis to recognise the historical variability of legal practices. This might be called the vertical richness of contextualised conceptual analysis, matched by the horizontal reach of the relational method, whose focus in Hart's hands on relations between law and coercion, morality, and social rules required us to look broadly at the function of what is said to be law and persuades us away from excessive reliance on observed data from particular situations which are local both to a particular legal culture and to a particular time. The relational method reminds us to look beyond the massive figures of judges in Anglo-American legal life to other officials and other experiences of life under law, and to avoid moving too quickly from local experience, particularly judicial experience and constitutional experience, to general conclusions about the nature of the concept of law. In this way contextualised conceptual analysis occupies a middle ground which admits the importance of local experience, yet attempts also to widen our understanding of that experience. This analysis reminds us of the importance of history to concept-formation, and the importance of working broadly and thoroughly with local investigations to constantly re-inform the concept of law. The resulting concept is contextualised because it is inclusive of a wide range of experience of life under law, yet it is admittedly theoretical and practically thin because it is a reflection of empirical investigations and locally situated conceptual investigations (into, e.g., interpretive principles accepted by judges in the context of Canadian Charter adjudication).

The historically-sensitive, partial contribution to general jurisprudence made by the contextualised concept may ultimately be a vague concept whose edges are not easily delineated. This vagueness is, however, both tolerable and expected of a concept emerging from relational study, and serving as a constantly revised conceptual backdrop for understanding of life under law, a prelude or constant accom- 
paniment to normatively committed and social scientific investigations of law. Unsurprisingly, then, given the emergent, reconstructed character of this clarificatory concept, it is not the only one. It is the particular result of one method calculated to reveal law as it is for the sake of the ordinary citizen who travels, pulling off the mask of law not by being practical or comprehensive, but by filling the gap between practically oriented, often judicially-focussed legal philosophy, and general accounts of the logic of norms. Contextualised conceptual analysis is then truly a middle way, its virtues identifiable only through its co-operation with accompanying investigations. It is nonetheless a powerful middle way, since it opens the possibility of analytical legal philosophy coming to terms with changes in social life judged by our observer's perspective in a world where the importance of law's morality, social rules, and coercion is changed, and changing. In the pluralist world inhabited by our citizen who travels, law's relation to morality is far more varied and complex than the relation claimed by Lord Devlin in the Hart-Devlin debate as he celebratedly claimed that a sense of $\sin$ in a society where morality and religion are conjoined is essential to effective administration of criminal law. ${ }^{32}$ The social rules to which our ordinary citizen is subject may be no more logically complex than those of Hart's generation, but the diversity of their sources and their force is ever-more bewildering in the globalizing world. And while the relation between law and coercion remains of fundamental interest as a persistent question, the way in which the ordinary citizen experiences this question has likely changed, as our citizen's mobility enables both evasion and sudden meetings with coercion.

\footnotetext{
32 "As a judge who administers the criminal law and who has often to pass sentence in a criminal court, I should feel handicapped in my task if I thought that I was addressing an audience which had no sense of sin or which thought of crime as something quite different." Devlin, Patrick, The Enforcement of Morals, Oxford, Great Britain, Oxford University Press, 1965, p. 4.
} 


\subsection{New Relations}

The contextualised concept of law is in some ways a surprisingly thin concept. In aiming to be historically sensitive and universal, it will be very broad; and in aiming to be constantly responsive to new phenomena so constantly under revision, its edges are likely to be vague and it is unlikely to be usefully put to service as a test for legality. Fortunately it need not be concerned with providing a test for legality, because such a test is provided by the complementary or companion inter-institutional view. The contextualised concept of law can rest its claim to an audience on the quality and relevance of its elucidation of relations between legality and social phenomena relevant to the inquirers. The choice of relations to investigate individually and in their convergence is accordingly crucial to the final value of the contextualised analysis of the concept. At the same time, the choice of relations to investigate may have unanticipated effects as the goal of clarification in aid of normative reform may once again take pride of place amongst the virtues of an analytical theory of law, generating fresh debates on method, application, data, and inference, pulling us away from worn-out debates, and toward new questions.

Since this paper is largely agenda-setting, we will confine ourselves in this closing section to a few words of justification regarding the relations we propose to investigate in future work. The relations we have chosen are those which are relevant to our ordinary citizen who travels, and in addition to travelling in a touristic way, sometimes migrates, and sometimes invests in various ways without migrating. This observer looks to legality as a tool and as an indicator of a certain kind of desirable stability, an increasingly valuable characteristic as social and environmental forces give rise to what we will call the era of the unsteady state.

We propose to begin satisfaction of this observer's interests at a point of overlap with Hart, in the relation between 
law and coercion, but at a particular point of special relevance to our citizen who travels: the relation between law and security, in the particular context of the law-state and the question of how to characterize the identity of a legal system or other forms of legality over time. Familiar examples of the challenge facing characterisation of law and security are easily found, from the decades-long absence of a law-state in Somalia, to the uncertain legal status of Kosovo, and on to the lengthy and varied period of uncertainty seen in the set of uneven regime and system-transitions in the context of the Arab Spring of 2011. Questions regarding the relation between law and security became particularly pronounced in that context as the rapid changes seen in countries such as Egypt and Tunisia in spring were not followed by equally rapid changes in other countries. Spring wore on into summer, and with it the Libyan insurrection, whose leaders at length gained recognition as states recognized the former rebels as the legitimate government of Libya. ${ }^{33}$ More recently questions of state identity, legality, and legitimacy have arisen in Syria as ongoing unrest verges on civil war. ${ }^{34}$ At the same time a different kind of security threat to the identity and continuity of the state has become visible as the European sovereign debt crisis has threatened the viability of Greece and other states with an unsustainably high debt-to-GDP ratio, ${ }^{35}$ rais-

33 For general analysis see Anderson, Lisa, "Demystifying the Arab Spring: Parsing the Differences between Tunisia, Egypt and Libya" (2011), 90 Foreign Affairs 3, 2-7.

34 Journalistic analysis of developments in Syria includes, for example, "Syria's Uprising: Growing Steadily Less Peaceful" The Economist online, December 19, 2011, available online at http://www.economist.com/node/21541978. Accessed January 14, 2012.

35 Eurostat, the Directorate-General of the European Commission responsible for provision of European-level statistical information, reports that "In 2010, 14 Member States reported debt to GDP ratios over the reference value of $60 \%$. Greece recorded the highest debt ratio with $144.9 \%$, followed by Italy with $118.4 \%$." "Structure of government debt in Europe in 2010," Eurostat Issue number 68/2011. Available online at: http://epp.eurostat.ec.europa.eu/portal/page/portal/product_details/publication?p_product_code $=K S-S F-11-068$. Accessed January $14,2012$. 
ing questions regarding the identity and continuity of the law-state, potentially especially far-reaching questions as a new European treaty may be negotiated to further mutualise economic planning, coincidentally reducing legal autonomy.

The ordinary citizen's concern with the relation between law and security is increasingly accompanied by concerns regarding the relation between law and environment. From the Asian tsunami of 2004 to the European heatwave of $2003^{36}$, and on to news of pervasive overfishing of global fish stocks, ${ }^{37}$ the ordinary citizen is inundated by news of environmental disaster and advocacy of substantial response on a state, supra-state and super-state basis. From climate change response to fish stock management, it is increasingly clear that humans' conduct in their environments has effects which cannot be contained within the boundaries of states of which those humans are citizens. The urgent need for effective response to environmental challenges raises fresh questions regarding the meaningful independence of states as a kind of super-state environmental law may become a precondition for further existence of states. Further questions are arising regarding the identity and continuity of states, as some island states such as the Republic of Kiribati may soon disappear beneath the waves under rising ocean waters. ${ }^{38} \mathrm{We}$ are familiar with the phenomenon of conquest - but immersion seems entirely new.

Finally, we intend to investigate a third relation, between law and technology, a relation with profound implications for conceptions of agency and autonomy in the context of

36 Stott, P. A. et al., "Human contribution to the European heatwave of 2003", (2004) 432 Nature 2, pp. 610-614.

37 Anticamara, J. A. et al., "Global fishing effort (1950-2010): Trends, gaps, and implications", 107 Fisheries Research, No. 1, 131-136.

38 Sanderson, Katharine, “Too late' to save Pacific island nation from submersion", Nature news online June 6, 2008. Available online at: http://www.nature.com/news/2008/080606/full/news.2008.880.html. Accessed Janaury 14, 2012. 
the law-state and other forms of legality. Limiting ourselves for the moment to the rise of the new information communication technologies, we note frequent discussion in the press regarding cyber-attacks supported by one government against the banking, military, and social information systems of other governments, all occurring within the supernational infrastructure of the internet. ${ }^{39}$ Is the internet now its own form of legality, perhaps like we might want super-state environmental law to be, a kind of substrate for all further legal activities by law-states? In this context we may also see virtual personalities and living wills, potentially creating artificial legal agents, perhaps unworrying at the level of the individual citizen, but rather more interesting from the point of view of legal theory as we consider the implications of virtual life. Consider, for example, the possibility that the Republic of Kiribati, submerged beneath the waves as a consequence of global failure to mitigate climate change, might emerge again as a virtual state operating as a law-state in all but territorial fashion, a persistent legal culture even in the absence of geographic boundaries, much like the social culture of the forcibly evicted and still angry former inhabitants of Diego Garcia in the British Indian Ocean Territories.40 Might our future see the impossibility of the demise of law-states, instead simply their transformation?

\section{CONCLUSION}

It is almost misleading to offer a conclusion to this paper, since it is above all a re-launch of a renewed research agenda for analytical jurisprudence, advocating a return to an expanded version of Hart's descriptive-explanatory, rela-

39 See, for example, the New York Times series on cyberwar. Available online at http://topics.nytimes.com/topics/features/timestopics/series/cyberwar/index.html Accessed January 14, 2012.

40 Vine, David, Island of Shame: The Secret History of the U.S. Military Base on Diego Garcia, Princeton, New Jersey, Princeton University Press, 2011. 
tional approach to characterisation of the concept of law. In bringing this approach to bear on law's relation to security, environment and technology, we aim simultaneously to offer a contextualised concept of law relevant to the interests of contemporary inquirers, and to redirect explanatory efforts away from an excessively narrow focus on the phenomena of adjudication, toward a broader range of phenomena from which a broad concept of law may be inferred, adequately reflective of the full range of relevant empirical phenomena. This contextualised concept of law may additionally put old problems in fresh perspective, encouraging us to see, for example, the questions of continuity and identity as pressing matters. A contextualised concept of law responsive to the concerns of our modern citizen may escape from the illusion fostered by stated-centred jurisprudence that the continuous, identity-stable state is legality's standard manifestation, whose interior needs further investigation while its exterior shell —its continuity of identity - may be taken for granted. As we begin to develop a contextualised concept of law via our investigation of new relations, the question of identity and continuity of legal orders gains a renewed prominence it has not had since the early 1970s, when John Finnis investigated identity and continuity in decolonization of Africa, in his "Revolutions and the Continuity of Law." 41 Pessimists might view this as analytical legal theory coming full circle in its enthusiasms, looking once again to the phenomena of revolution as a reason to engage the persistent question of the identity and continuity of legal order. Optimists like us see the possibility of new and better answers to the persistent question, which is not just persistent but of new importance in the new era of the state made unsteady not just by revolution but by other developments as well. The relation of law to coercion, explored by Finnis as the relation of law to secu-

41 Finnis, John, "Revolutions and Continuity of Law", in Philosophy of Law, Collected Essays: Volume IV, Oxford, Great Britain, Oxford University Press, 2011, 407-35. 
rity, remains important to our worldly citizen, albeit increasingly at the scale of a given legal order, and not just legal obligation by legal obligation in a single-law state. As the state's role as a law-giver is increasingly shared with other legal orders, and those orders and the state's role in the community of legal orders is affected by changing relations between law and environment, and law and technology, the question of the identity and continuity of legal orders is justifiably regarded as demanding attention at least equal to that historically given the persistent questions of the nature of municipal legal systems and legal obligation within them, and the relation of legality in that context to morality, coercion, and social rules. If we succeed in carrying out the research agenda we have advocated, via a renewed relational approach taking the persistence of legal orders as a major challenge to descriptive-explanatory legal theory, we may contribute to the destruction of the fiction of the centrality of the state to the nature of legality, and in that way, contribute one step to pulling the mask off law.

\section{BIBLIOGRAPHY}

ANDERSON, Lisa, "Demystifying the Arab Spring: Parsing the Differences between Tunisia, Egypt and Libya" (2011), 90 Foreign Affairs 3.

ANTICAMARA, J. A. et al., "Global fishing effort (1950-2010): Trends, gaps, and implications", 107 Fisheries Research, No. 1.

Bentham, Jeremy, A Comment on the Commentaries, Chap. II, s. 1, in The Collected Works of Jeremy Bentham, London, Great Britain, Clarendon Press, 1968.

-, A Fragment on Government, in BURNS, J. H. and HART, H. L. A. (eds.), introd. Harrison, R., Cambridge, Great Britain, Cambridge University Press, 1998.

Coleman, Jules, The Practice of Principle, Oxford, Great Britain, Oxford University Press, 2001. 
Culver, Keith, "Leaving the Hart-Dworkin Debate" (2001), 50 University of Toronto Law Journal 4.

- and GIUDICE, Michael, Legality's Borders, New York, United States, Oxford University Press, 2010.

DEVLIn, Patrick, The Enforcement of Morals, Oxford, Great Britain, Oxford University Press, 1965.

Dworkin, Ronald, Law's Empire, Cambridge, Massachusetts, Belknap Press of Harvard University Press, 1986.

Dyzenhaus, David, "Positivism's Stagnant Research Programme” (2000), 20 Oxford Journal of Legal Studies 4.

FINNIS, John, "Revolutions and Continuity of Law", in Philosophy of Law, Collected Essays: Volume IV, Oxford, Great Britain, Oxford University Press, 2011.

FRANK, Jerome, "Preface to the Sixth Printing", Law and the Modern Mind, Gloucester, Massachusetts, Peter Smith, 1970. First published in 1930.

FUller, Lon, The Morality of Law, 2nd edn., New Haven, United States, Yale University Press, 1969.

GREEN, Leslie "General Jurisprudence: A 25th Anniversary Essay" (2005), 25 Oxford Journal of Legal Studies 4.

HACKER, P. M. S., "Hart's Philosophy of Law", in HACKER, P. M. S. and RAZ, J. (eds.), Law, Morality, and Society: Essays in Honour of H. L. A. Hart, Oxford, Great Britain, Clarendon Press, 1977.

HART, H. L. A., "Commands and Authoritative Reasons", in Essays on Bentham, Oxford, Great Britain, Clarendon Press, 1982.

- "Law in the Perspective of Philosophy", in Essays in Jurisprudence and Philosophy, Oxford, Great Britain, Clarendon Press, 1983.

- The Concept of Law, 2nd edn., Oxford, Great Britain, Clarendon Press, 1994. 
- "The Demystification of the Law", in Essays on Bentham, Oxford, Great Britain, Clarendon Press, 1982.

LEITER, Brian, Naturalizing Jurisprudence, Oxford, Great Britain, Oxford University Press, 2007.

MACCORMicK, Neil, H. L. A. Hart, $2^{\text {nd }}$ edn., Oxford, Great Britain, Oxford University Press, 2008.

Morgan, Edmund, "The Price of Honour", New York Review of Books, XLVIII, No. 9, May 31, 2001, pp.

Morton, F. L. and KNOPFF, R., The Charter Revolution and the Court Party, Peterborough, Ontario, Broadview Press, 2000.

RAZ, Joseph, "Authority and Justification” (1985), 14 Philosophy and Public Affairs 3.

_- "Authority, Law and Morality" (1985), 68 The Monist.

_ _ "Explaining Normativity: On Rationality and the Justification of Reason" (1999), 12 Ratio.

_- Engaging Reason, Oxford, Great Britain, Oxford University Press, 2000.

_ sionary Reasons", in Practical Reason and Norms $2^{\text {nd }}$ edn., Princeton, New Jersey, Princeton University Press, 1990.

- , The Authority of Law, Oxford, Great Britain, Clarendon Press, 1979.

SANDERSON, Katharine, "Too late' to save Pacific island nation from submersion" Nature news online June 6, 2008. Available online at: http://www.nature.com/ news/2008/080606/full/news.2008.880.html. Accessed Janaury 14, 2012.

SANTOS, Boaventura de Sousa, Toward a New Legal Common Sense: Law, Globalization, and Emancipation, 2nd edn., London, Great Britain, Butterworths, 2002. 
Simpson, Brian, "Herbert Hart Elucidated" (2006), 104 Michigan Law Review 6.

STOTT, P. A. et al., "Human contribution to the European Heatwave of 2003" (2004), 432 Nature 2.

TAMANAHA, Brian, A General Jurisprudence of Law and Society, Oxford, Great Britain, Oxford University Press, 2001.

_- "Socio-Legal Positivism and A General Jurisprudence" (2001), 21 Oxford Journal of Legal Studies 1.

TWINING, William, General Jurisprudence: Understanding Law from a Global Perspective, Cambridge, Great Britain, Cambridge University Press, 2009.

- Globalisation and the Legal Theory, London, Great Britain, Butterworths, 2000.

VINE, David, Island of Shame: The Secret History of the U.S. Military Base on Diego Garcia, Princeton, New Jersey, Princeton University Press, 2011.

Von DANIELS, Detlef, The Concept of Law from a Transnational Perspective, Surrey, England, Ashgate Publishing.

WALDRON, Jeremy, "Hart and the Principles of Legality", in KRAMER, M. H. et al. (eds.), The Legacy of H. L. A. Hart: Legal, Political, and Moral Philosophy, Oxford, Great Britain, Oxford University Press, 2008.

WYATT-BROWN, Bertram, The Shaping of Southern Culture: Honour, Grace, and War, 1760s-1880s, Chapel Hill, North Carolina, University of North Carolina Press, 2000. 